\title{
Palang Pintu: Exploring Cultural Philosophy Value of Betawi Community
}

\author{
Titi Handayani ${ }^{1,}$ Putri Hidayah ${ }^{2,}$ Aulya Safiyna Nuuril Anwari ${ }^{3,}$ \\ Andhy Trianto ${ }^{4,}$ Indra Himawan Susanto ${ }^{5, *}$ Yetty Septiani Mustar ${ }^{6}$
}

\author{
${ }^{1,3,5,6}$ Department of Health Education and Recreation, Universitas Negeri Surabaya, Surabaya, Indonesia \\ ${ }^{2}$ Department of Accounting Education, Universitas Negeri Surabaya, Surabaya, Indonesia \\ ${ }^{4}$ Department of Historical Education, Universitas Negeri Surabaya, Surabaya, Indonesia \\ *Corresponding author. Email: indrasusanto@unesa.ac.id
}

\begin{abstract}
Palang Pintu is one of the traditions among the Betawi community, which combines martial arts with Pantun literature passed down from generation to generation by the Betawi tribe. However, with the current culture acculturation, the district has begun to forget this tradition. This qualitative research aims to explore the philosophical value of the Palang Pintu to strengthen the rules and arts of the sport of the Betawi people. This study was conducted at Sanggar Golok Jaya, Bekasi City. Data were collected by observations and in-depth interviews with prominent cultural conservationists, the sports government, and the general public. These research findings revealed various philosophical values in the traditional sports movement of Palang Pintu consist of religious, spiritual, cultural, traditional, politeness, morals, respect, noble, learning, solidarity, beauty, aesthetic, and material value. Promote the Palang Pintu culture by adding materials to history lessons and carrying out various annual Cultural Festival events are highly recommended, thus increasing efforts to teach the philosophical values of the Palang Pintu that can shape the community's character in preserving culture.
\end{abstract}

Keywords: Philosophical values, Palang pintu, Sports tradition, Preserving culture

\section{INTRODUCTION}

Palang Pintu is one of the traditions that has become the identity of the Betawi people and has been part of the Betawi traditional wedding ceremony procession since the time of the ancestors, which combines the arts of silat, witty rhymes, and reading scriptures. al-Qur'an is the dominant thing in the Palang Pintu tradition [1], [2]. "Previously, this was not called Palang Pintu, but "seize the cormorant" if in Bekasi City, which required the groom to bring the cormorant which the prospective bride will contest. However, because over time, people no longer call it by the name of fighting over the cormorant but Palang Pintu, because the bride will confront the groom" [3]. Meanwhile, the Development and Achievement Division (Binpres) Koni and the Indonesian Community Recreational Sports Committee (KORMI) revealed that Palang Pintu is one of the ancestral heritage or cultural traditions of the Betawi people, which is an acculturation of several literary arts, music, and martial arts [4].

Palang Pintu has values that are implemented in line with social processes, divided into five stages, starting from greetings, rhymes, fighting, Sike, and shalawat duster. Each location has a philosophical meaning [5]. Palang Pintu is inseparable from the traditional fighting sport, which is now known as Pencak Silat, but in Bekasi City, it is better known as Silat Betawi. The silat movement in Palang Pintu is likened to a man who must be responsible to the bride to take care of and protect their family [4].

The introduction of Palang Pintu culture itself cannot be separated from digital transformation. Introducing Palang Pintu through social media accounts provided by researchers so that the general public can access information in history, tradition, art, and culture and 
learn through videos every stage of the Palang Pintu movement can facilitate the community in getting to know the culture. Digital transformation is a change influenced by digital technology in every aspect of people's lives, and the internet has become an inseparable part of everyday life [6]. Increasing the introduction of the Palang Pintu tradition can directly impact the dissemination various information (Online). Concerning this, it is necessary to identify the philosophical exploration of Palang Pintu to strengthen traditional sports and Betawi arts so that the younger generation can know what intellectual values are contained in this tradition and can be used at the same time.

\section{METHODS}

The approach used in this research is a qualitative approach that is carried out offline and online. Data collection is done offline when researchers observe directly, and online data collection uses G-from to find out how far the community knows the Palang Pintu tradition. The distribution is carried out to the younger generation and the general public by collecting 100 respondents.

The subjects in the study were primary subjects and secondary subjects. Primary issues were obtained from each regional informant studied, with the type of crucial informants of the study being local cultural security guards and Betawi culture experts. Secondary subjects were obtained from supporting information to meet the level of validity of the data. The researchers confirmed the writing of the research findings. Next, an interview was conducted with an activist of the Palang Pintu tradition, namely Bang Dedi Wijaya, an informant for Sanggar Jaya Golok Bekasi City, and an interview was conducted with Habibie, as vice the chairman of KORMI as well as BIMPRES KONI City Bekasi.

\section{RESULTS AND DISCUSSIONS}

This research explored the philosophical value of Palang Pintu, efforts to examine the potential of Palang Pintu as reinforcement of traditional sports, and promoting Palang Pintu Culture in history learning materials.

\subsection{Exploring the philosophy value of Palang Pintu}

Philosophical values are beliefs about how to behave and the final goals that individuals want and serve as principles or standards of life that are contained in a person's view with the basic concept of aspired life [7]. Betawi society is egalitarian, which means open. The value of the Palang Pintu Philosophy itself occurs like a rhyme, a competition rhyme between the male and female parties, which can be interpreted as a man when proposing to a woman. That is how he diplomatically communicates with the women because of the Betawi tradition. The men come to the women's residence called besan. The philosophical values in it are that one must be able to diplomacy with women to be accepted by men [4]. There are several movements in the Palang pintu tradition, including:

\subsubsection{Greetings}

Before doing the opening greetings, the man approaches the women's territory accompanied by firecrackers installed when the groom, proving that the presence of the prospective besan has closed the bride's place. The greeting starts from the bride and asks the purpose of the groom's arrival. The values contained in the greeting are as follows:

\subsubsection{Religious value}

Religious value is a value that in the relationship between the bride and groom with various characteristics of Indonesian society is a social attitude that is applied through friendship with various elements of the Indonesian people is a social attitude that is used through ties of friendship. An awareness and plan to prepare students in terms of knowledge, understanding, and living, practicing to arise to believe in the religion adopted [8]. Faithfulness, honesty, sincerity, and responsibility can be instilled in students through examples of both internal and external [9]. Revitalizing the religious values contained in the palang pintu tradition proves that this tradition has been carried out from generation to generation to be preserved in the life of the nation and state.

\subsubsection{Moral Value}

Moral values are behaviors reflected in the initial procession of the doorstop, namely the greeting, which is a form of respect for the men who come to the women's residence. It is included in the attitude of politeness, which is a form of etiquette for men to visit. So with the moral value in the greeting, it is hoped that it can provide learning that every time to call or come to a place, it must be preceded by greetings as a form of respect and courtesy.

\subsubsection{Character value}

Character values will be part of self-reflection from generation to generation to understand the meaning of marriage as a form of responsibility towards oneself and one's partner. A belief that in the doorstop tradition during the opening greeting procession is that a group brings offerings of crocodile bread. Crocodile bread is believed to symbolize loyalty, where the groom is ready to marry and is loyal to his partner.

\subsubsection{Pantun Reply}

Palang Pintu is synonymous with rhyme competition. Even though it is advice or humorous, we must use rhymes [3]. A spokesperson for the bride and groom dialogue with each other and inserted by opening the pantun. Pantun is a poem known by anyone who has made it, but with rhymes, it can describe the community's identity as a whole [10]. The rhymes used in Palang Pintu are usually divided into two verses of advice and witty rhymes, which are as follows: 


\subsubsection{Advice}

Pantun advice is a poem that contains advice to others intending to invite a better direction in living life [11]. The existence of the value of solidarity, the value of tolerance, and the importance of beauty, these three values strengthen the bonds of brotherhood or friendship between the Betawi people. The values contained in the advice poem are as follows:

\subsection{Aesthetic value}

The aesthetic value is contained in the choice of words or rhymes in the poem. This is because the structure of the verse, which has a-b-a-b rhyme, makes the rhyme an excellent literary work to listen to, for example, from a rhyme of advice:

\section{Pants starts from the bride:}

"Bang, the gong house is the Dutch house... The fence is wire, the pole is here... I want to ask the group from where you are going, where are you going?... If you come here, you must excuse me".

\section{Then the bridegroom replied:}

"In advance, I'm sorry, bro... If you come to the group, it's not pleasing to the heart... Before that, greetings... Assalamualaikum Wr.Wb"

"Eating ice puter at the Friday market... While sitting at the date palace... If it wasn't for what's inside... I wouldn't have sent my boss here."

The way of speaking in the Pantun Palang Pintu usually uses a high-pitched language because Bekasi people have a language. The characteristic of speaking is done in a high-pitched spontaneous way.

\subsection{Courtesy Value}

The value of politeness is contained in the type of advice rhyme. The direct example can be seen in the part when the Champion of the groom says "excuse me" when he is about to enter the bride's house where the event is.

\subsubsection{Limerick}

This witty rhyme is a type of rhyme that contains humor. It aims to entertain people who listen to it, sometimes it is also used as a medium to quip each other in an atmosphere full of intimacy so as not to offend, and it is hoped that the atmosphere will become more cheerful. The values contained in the advice poem are as follows:

\subsection{Solidarity Value}

The value of solidarity begins with a witty rhyme used in the Palang Pintu tradition. For example, it can be seen from the intimacy between the two champions. They insinuate each other regardless of the feelings of one party. All of these things are the influence of the value of solidarity [12].

\subsection{Tolerance Value}

The value of tolerance has contained the type of witty rhyme; this is because the purpose of the funny verse is to melt a tense atmosphere where usually the contents of this rhyme contain satire.

\subsubsection{Beklai (Adu Silat)}

Bella in the Palang Pintu procession is a form of Betawi martial art known as martial arts. It has several values or meanings based on their respective movements, which include:

\subsubsection{Blow}

The material value includes the strength of the hand muscles when performing the accuracy of the stroke. The value of art is a movement to attack with a calculated and precise target [13].

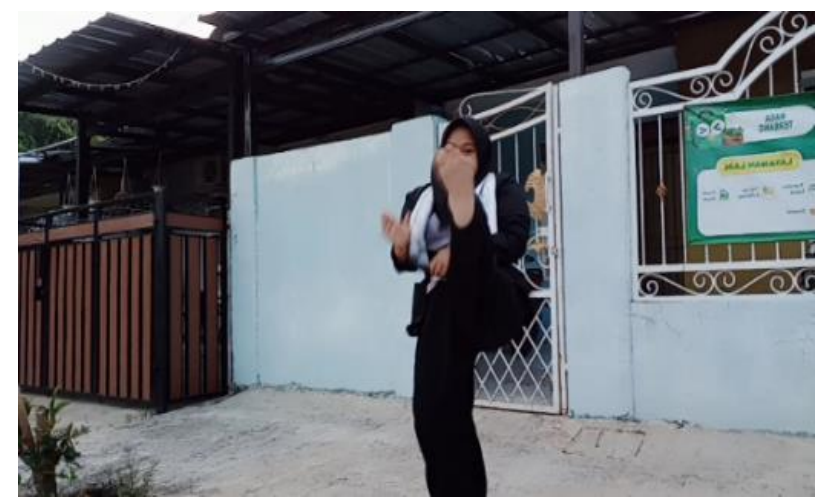

Figure 1 Blow

\subsubsection{Kick}

Skill value is a harmonious and attractive movement value and self-control with the obligation not to act recklessly. Score material in kicks can benefit the body in the legs when making attacks on the target.

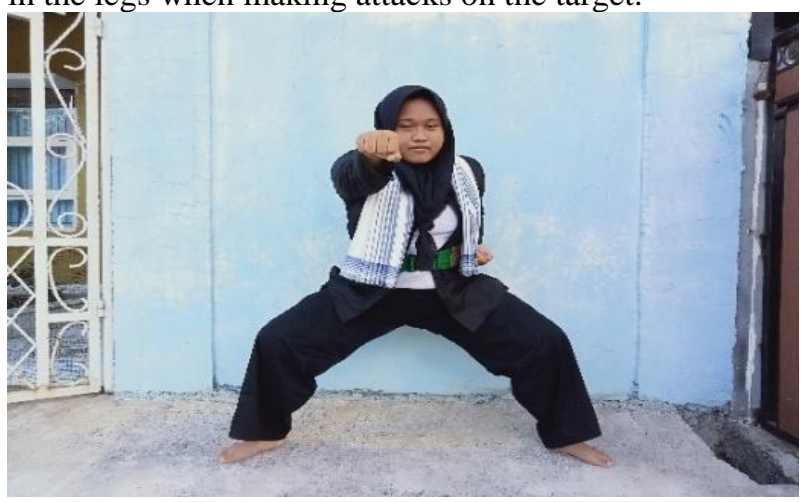

Figure 2 Kick

\subsubsection{Defence}

Aesthetic value in every movement in the form of up, down, and back counter-movements are done skillfully in making effective and efficient movements to ensure the groom's physical and mental readiness while protecting the bride. 


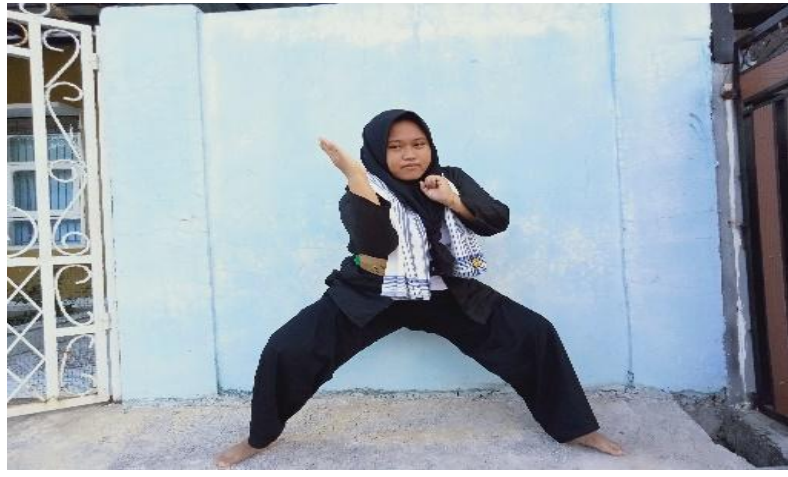

Figure 3 Defence

\subsubsection{Sike (Recitation of the Holy Quran)}

Sike is the recitation of the holy verses of the Qur'an, which is done after the men beat the women during beklai. The meaning of Sike on Palang pintu has several values, namely:

\subsubsection{Religious Value}

The religious values in Sike teach to practice spiritual teachings in everyday life. The sike procession requires the groom to build a religion-based family and become a peaceful family full of love and affection.

\subsubsection{Spiritual Value}

The spiritual value is reading the holy verses of the Qur'an with silence and wisdom, which gives meaning to the groom that with this event, there will be duties and responsibilities that must be carried out in guiding his wife and family.

\subsection{Efforts to Explore the Potential of Palang Pintu to Strengthening Traditional Sports}

Martial art is a game that relies on agility and many patterns and flowers in its steps, martial arts, and folk dance; material art is developed to be part of state defense education to fight foreign invaders, as a unifying tool for the nation, and plays a role in defending the country [14]. Besides, silat can protect oneself from numerous attacks based on agility and agility and pay attention to the opponent's movements [15]. The definition of Pencak silat has a comprehensive meaning. It has a clear function, including martial art as a tool for training, as a means of self-defense, as a vehicle for spirituality, performance, or art, and as a teaching aid means defending the nation [14].

Historically, Pencak silat is a skill that functions according to the needs of the actors in facing various challenges, especially those from nature, animals, and humans [16]. Betawi stories from the past were often found by champions who were always fighting in almost every village and would test their village visitors' abilities about their martial arts ability. Betawi people then adopt this in the wedding procession to test the seriousness of the men [17].
Culture and traditions that develop in the community are cultural tourism assets with their values and advantages and a chain of inheritance and Indonesian cultural wealth [18]. Palang pintu is performed when the groom and his entourage come to the bride's Palang Pintu house to sit and carry out the marriage contract. Still, now the Palang Pintu performance has been modified by using it not only in Betawi traditional weddings. Palang Pintu is currently one of the various events generally held by the community or government agencies that still have a relationship with the city of Jakarta and its surroundings, such as circumcision events, opening government events, building inauguration, and welcoming government officials [19]. Material art in Palang Pintu is considered a dance art because it uses body movements to deliver.

On the other hand, Palang pintu is considered a martial art. The Palang Pintu dance is just a flower of the actual content of Pencak silat, material art is indeed a martial art, but Pencak silat dance is a performance that invites Betawi youth to learn Pencak silat as a martial art, a genre, and material for silat folklore dance art that is inherited heredity traditionally [20]. At this stage, the prospective groom is tested to provide several Pencak silat attractions to complete one of the requirements set by the bride and carried out in the form of Palang pintu [21]. The Palang Pintu tradition is unique in the stages of a traditional sports movement called Beklai, the settings of this movement are the same as the Indonesian Pencak Silat Association (IPSI), which are generally carried out with basic activities of punches, kicks, and slashes, but Beklai (Adu Silat) has the right element of the artistic movement in every move. Jaya Golok has the main instrument used in the show, namely the Betawi Golok. The main movement of Beklai (Adu Silat) Jaya Golok is to use one leg for what is called jejengkrikan. Betawi people are then called Jingkrik or Cingkrik.

The traditional sport of beklai (Adu Silat) has its uniqueness in its use so that it is different from Pencak silat in general. The costumes worn by the Palang Pintu players consist of everyday Betawi traditional clothes. For men, it is a Koko shirt (Sadariah). Betawi's Koko shirt is plain in color. At the same time, at the bottom, he wears batik-patterned trousers with a primary shade of white, brown, or black, usually worn in every performance of the Palang Pintu fighter heroes. Punch refers to a local term for martial arts in Betawi culture dominated by a hitting motion [22].

Betawi people also usually call pencak silat in Palang Pintu by the name (Pukulan). One of the most famous Betawi martial arts is the Cingkrik silat. At first, this is just a game and not to show physical strength or 
character. Betawi pencak silat is famous for its flow of moves such as: Crossing Centipede, Cingkrik, Merak Ngigel, Beksi, Gerem Naga, Gie Sau, and many more. Learning Pencak silat for Betawi children is an obligation other than studying the Qur'an. In addition, Pencak silat has been taught from generation to generation, and as adults, they begin to look at the hermitage founded by Jawara, who is considered outstanding and robust.

\section{CONCLUSION}

The Palang Pintu tradition is a cultural heritage in the Betawi traditional wedding ceremony. Palang Pintu is usually performed at ceremonial events at weddings or welcoming guests, and Palang Pintu is an acculturation of several arts and sports in Indonesia. There are rhymes, Pencak silat, and also a kind of qasidahan. Palang pintu is also a custom to fight over the cormorant from the hands of the groom's Champion, because previously it was not called palang pintu, but fought over the cormorant. The exploration of Palang Pintu's philosophical values influences and involves the younger generation in many ways. Digital transformation has a significant effect on change and improvement of excellence and cultural preservation, and social media can be an effort to increase understanding about Palang pintu. Besides, promoting the Palang Pintu culture by adding history lessons and holding various annual Cultural Festival events is highly recommended. Thus, it can increase efforts to teach the Palang Pintu philosophical values that can shape the character of each generation in preserving culture.

\section{REFERENCES}

[1] D. Anggraeni, A. Hakam, I. Mardhiah, and Z. Lubis, "Membangun Peradaban Bangsa Melalui Religiusitas Berbasis Budaya Lokal (Analisis Tradisi Palang Pintu Pada Budaya Betawi)," Studi Al-Qur'an, vol. 15, no. 1, pp. 95-116, 2019.

[2] I. dan A. S. Suryani, "Strategi Komunitas Betawi Dalam Mempromosikan Tradisi Palang Pintu (Studi Kasus Pada Event Festival Palang Pintu XI)," Jurnal Komunikasi, vol. 8, no. 2, p. 5, 2017.

[3] D. Wijaya, "Pengertian Palang Pintu," Hasil wawancara pribadi, p. 04 Agustus 2021, 2021.

[4] Habibie, "Pengertian Palang Pintu," Hasil wawancara pribadi, p. 24 Agustus 2021, 2021.

[5] A. Melinda and S. Paramita, "Makna Simbolik Palang Pintu Pada Pernikahan Etnis Betawi di Setu Babakan," Koneksi, vol. 2, no. 2, p. 218, 2019, doi: 10.24912/kn.v2i2.3888.

[6] R. Oktavenus, "Analisis Pengaruh Transformasi Digital dan Pola Perilaku Konsumen Terhadap Perubahan Bisnis Model Perusahaan di Indonesia," Jurnal Manajemen Bisnis dan Kewirausahaan, vol. 3, no. 5, Art. no. 5, Nov. 2019, doi: 10.24912/jmbk.v3i5.6080.

[7] Dhidhik Setiabudi, "Nilai-Nilai Filosofis Dalam Serat Wedha-MA-Sapta," 2021, 2021. https://pendekarjawa.wordpress.com/nilai-nilaifilosofis-dalam-serat-wedha-ma-sapta/

[8] S. P. Sumenep, "ISSN 2548-9119 Implementasi Nilai Religius Melalui Budaya Sekolah: Studi Pendahuluan Penanaman nilai religius adalah suatu kesadaran dan terencana demi menyiapkan peserta didik dalam hal mengenal, dan memahami, menghayati, mengamalkan sehingga timbul," no. c, pp. 15-24.

[9] M. Murdiono, "Strategi Internalisasi Nilai-Nilai Moral Religius Dalam Proses Pembelajaran Di Perguruan Tinggi," Cakrawala Pendidikan, vol. 1, no. 3, Art. no. 3, 2010, doi: 10.21831/cp.v1i3.239.

[10] A. Yunaldi, "Istiadat Perkawinan Melayu Sambas," vol. 2, no. 2, pp. 111-122, 2018.

[11] C. N. . Nurmina. N. Rafika, "Analisis Nilai Sosial dalam Adat Perkawinan Masyarakat Aceh di Kecamatan Jeunieb Kabupaten Bireuen," vol. 1, no. (01), pp. 31-39, 2020.

[12] Rahman, Zakaria, N. Tristiantari, and A. W. Sakti, "An Analysis of Symbolic Meanings in Palang Pintu Tradition of the Betawi Wedding Ceremony," vol. 509, no. Icollite, pp. 599-604, 2020, doi: 10.2991/assehr.k.201215.093.

[13] D. Djuharni, Sonhaji, R. G. Mais, and N. A. Aziz, "Artikulasi Nilai Budaya "Palang Pintu" dan Sistem Informasi Akuntansi," Jurnal Riset dan Aplikasi: Akuntansi dan Manajemen, vol. 4, no. 3, pp. 342-359, 2020, doi: 10.33795/jraam.v4i3.0010.

[14] Kumaidah Endah, "Penguatan Eksistensi Bangsa Melalui Seni Bela Diri Tradisional Pencak Siat'," vol. 148, pp. 148-162, 2019.

[15] I. D. Wilson, "The politics of inner power: the practice of Pencak silat in West Java," Ian Douglas Wilson, p. 338, 2019.

[16] S. Ediyono and S. T. Widodo, "Memahami Makna Seni dalam Pencak Silat," Panggung, vol. 29, no. 3, 2019, doi: 10.26742/panggung.v29i3.1014.

[17] A. Bahtiar and A. Nasrullah, "Multiliterasi dalam Pembelajaran Bahasa Indonesia untuk Penutur Asing (BIPA) Berbasis Sastra Warna Lokal Betawi Di Uin Syarif Hidayatullah Jakarta," Bahasa: Jurnal Keilmuan Pendidikan Bahasa dan Sastra Indonesia, vol. 1, no. 1, pp. 28-43, 2019, doi: 10.26499/bahasa.v1i1.25.

[18] S. Literate and J. I. Indonesia, "View metadata, citation, and similar papers at the core. ac. the UK," vol. 5, no. 2, pp. 274-282, 2020.

[19] S. Aisya, "Struktur Teks, Konteks Pertunjukan, Dan Ajaran Islam Pada Palang Pintu Pada Pernikahan Adat Betawi," Arkhais - Jurnal Ilmu Bahasa dan Sastra Indonesia, vol. 7, no. 1, p. 25, 2016, doi: 10.21009/arkhais.071.04.

[20] J. Sista Siregar and S. Irtawidjajanti, "Development of Palang Pintu As an Edutainment in Venetië van Java (Batavia)," KnE Social Sciences, vol. 3, no. 12 , p. 516, 2019, DOI: 10.18502/kiss.v3i12.4120. 
[21] R. A. Wibowo and L. Ayundasari, "Tradisi Palang Pintu masyarakat Betawi dalam konteks budaya Islam," Jurnal Integrasi dan Harmoni Inovatif IlmuIlmu Sosial, vol. 1, no. 1, pp. 38-44, 2021, doi: 10.17977/um063v1i1p38-44.
[22] A. Ningrum and M. Yoesoef, "Sustainability of Buke Palang Pintu Tradition in Betawi Modern Society in Jakarta," 2019, DOI: 10.4108/eai.21-122018.2282674 . 